\title{
Proximate Composition and Determination of Heavy Metal Content in Indian Fish using ICP-MS after Closed Vessel Micro Wave Digestion
}

\author{
Sreenivasa Rao J. , Longvah T. \\ Food Chemistry Division, National Institute of Nutrition, Indian Council of Medical Research, India
}

Copyright (C) 2016 Copyright (C) 2016 by authors, all rights reserved. Authors agree that this article remains permanently open access under the terms of the Creative Commons Attribution License 4.0 international License.

\begin{abstract}
The objective of the present study was to investigate the heavy metal content in fresh water fish collected from the outlets of twin cities of Hyderabad and Secunderabad, Andhra Pradesh, India. The heavy metal content of fresh water fish varieties was investigated using Inductively Coupled Plasma Mass Spectrophotometer (MD-ICP-MS) after microwave digestion. Heavy metal content in fresh water fish were ranged from $52-680 \mu \mathrm{g} / \mathrm{kg}$ for Nickel in Rastrelliger kanagurta and Stromateus sinensis, $38-690 \mu \mathrm{g} / \mathrm{kg}$ for Arsenic in Rastrelliger kanagurta and Pompus argenteus, 3-62 $\mu \mathrm{g} / \mathrm{kg}$ for Cadmium in Masto symbollon and Pompus argenteus and 27-108 $\mu \mathrm{g} / \mathrm{kg}$ for Lead in Panaeus monodon and Rastrelliger kanagurta respectively. Results were in accordance with recommended human daily intake values except for arsenic, which were in agreement with $\mathrm{WHO} / \mathrm{FAO}$ recommended values. Since the available data for heavy metal content in fish is scanty, efforts were made to present a precise data for the same as estimated on ICP-MS. This study may provide information on important heavy metal concentrations of fresh water fish and shell fish and therefore provides an essential baseline data with which future levels may be compared and evaluated. Results were in accordance with recommended daily intake allowance by WHO/FAO.
\end{abstract}

Keywords Fresh Water Fish, Heavy Metals, ICP-MS, Microwave Digestion

\section{Introduction}

Fish and shellfish are one of the major sources of animal protein and have been widely accepted as a good source of nutrients for the maintenance of a healthy body. These are also increasingly marketed for their health benefits to consumers [1]. It is widely consumed in many parts of the world and valued for its omega 3 fatty acids, which is reported to reduce the risk of heart diseases, stroke and preterm delivery $[2,3,4]$. It is unfortunate that we, human beings without realizing the consequences of pollution, do a lot of activities that terribly ruin the nature, resulting in the denial of healthy environment to our successors. Water contamination is one of the serious concerns that affect the marine ecosystem with high concentration of trace metals. According to Jingaram [5] the coastal or river waters are contaminated by the dumping of industrial wastages. The metals accumulated in these waters infect the humans by direct consumption of water or through consuming the affected organisms like fishes [6,7] claim that when the level of trace metal concentrations exceeds the stipulated level; it turns out to be toxic. Very recently, the work in Mc Lintock [8] has stated that the higher level of metal concentration will bring shattering effect to the ecological balance by altering the range of organisms in water.

Among a variety of substances entering the soil, inland waters and the ocean as waste products, especially substances like heavy metals like Nickel (Ni), Arsenic (As), Cadmium $(\mathrm{Cd})$ and Lead $(\mathrm{Pb})$ create long term problems. Not only they accumulate in organisms and circulate in food chain, also remain in the ecosystem in sediments for longer(9). The increasing levels of heavy metals in the environment, their entry into the food chain, and the overall health effects on people who consume fish are of major concern to researchers in the field of food and nutrition, because heavy metal toxicity is a result of long term, low level exposure to pollutants through air, water and numerous consumer food products. Heavy metals can be classified as potentially toxic (arsenic, cadmium, lead, mercury, etc.,) probably essential (nickel, vanadium, cobalt) and essential (copper, zinc, iron, manganese etc...) [9]. Food is usually the most important path by which toxic elements enter the body e.g., fish and shellfish are known to accumulate heavy metals. Heavy metals are natural component of the earth's crust that cannot be degraded or destroyed and they occur at a wide range of concentrations and with a broad array of chemical attributes. Recent studies have shown that even low levels of $\mathrm{Cd}, \mathrm{Pb}, \mathrm{As}$ and $\mathrm{Hg}$ can cause health complications in humans 
$[10,11]$. Cd causes kidney dysfunction, hyper tension, and osteoporosis and is also a potential carcinogen $[12,10]$. $\mathrm{Pb}$ toxicity is associated with naturism; a disease characterized by anaemia, hematopoietic, renal toxicity and peripheral neuropathy [13]. The most toxic form of arsenic found in food and water are the inorganic As (III) and As (V) which is classified as carcinogen by International Agency for Research on Cancer (IARC) [14]. Considering the potential toxicity of heavy metals, there has been a growing interest in determining heavy metal levels in the fresh water and marine environment and attention was drawn to the measurement of contamination levels in public food supplies, particularly in fish.

Among the Asian countries India ranks second in aquaculture, fourth largest producer of fish and one of the top leading exporters of sea foods [15]. Literature is scarce on the availability of heavy metal content of fish and shell fish in the Indian market. Therefore the present study attempts to provide information on the heavy metal levels in fresh water fish and shellfish species collected from the twin cities of Hyderabad and Secunderabad using Inductively Coupled Plasma Mass Spectrophotometry (ICP-MS).

The data provides useful information to consumers in choose fish and shellfish, besides to complement information in Indian Food Composition database. Several reliable analytical methods like Colorimetric and Atomic Absorption Spectrophotometer are available for monitoring heavy metals in food samples, but ICP-MS is being the most sophisticated and reliable technique, fast quantitative, high sensitivity, good precision and accuracy. Isotope ratio measurements were also possible using ICP-MS and interferences relatively few in number compared to other analytical techniques such as ICP-AES. Based on the above reasons efforts were made to present a precise data on heavy metals in a large variety of fish and shell fish. It is expected that the results of this research will assist in acquiring information about the level of toxic metals in fresh water fish.

\section{Materials and Methods}

\subsection{Reagents}

All chemicals used were analytical grade. Ultra pure water was obtained from a Millipore water system (Millipore), Ultra pure Nitric acid $\left(\mathrm{HNO}_{3}\right.$, Merck) was used to digest the samples. Stock standard solutions of arsenic, cadmium, nickel and lead concentration containing $10 \mu \mathrm{g} / \mathrm{ml}$ in $2 \%$ $\mathrm{HNO}_{3}$ was prepared [16]. The certified reference materials (CRM) were procured from National Institute of Standard Technology (NIST-8436) and European Commission (EC-804) and used for method validation.

\subsection{Collection of Fish Sample}

Different varieties of fresh water fish species (weight ranges from 0.3 to $2.0 \mathrm{~kg}$ ) were presented in Table- 1 with their local name and scientific name. All varieties of fresh water fish were collected from local markets of twin cities of Hyderabad and Secunderabad. The targeted species were commercial fish and shellfish available to consumers in Hyderabad.

In the present study, fish and shellfish samples were collected by stratified random sampling procedure. This approach is the most suitable method for generating food composition database [17]. Collected fish samples were immediately curved in ice, kept in polystyrene boxes and transported to laboratory to sustain freshness. Upon arrival to laboratory, fish and shellfish were individually measured for their total body weight and length.

Table 1. List of Fresh water fish collected from markets with a narrow range of weight and length

\begin{tabular}{|c|c|c|c|c|c|}
\hline Local name & Common Name & Scientific name & $\begin{array}{c}\text { Edible } \\
\text { portion/kg }\end{array}$ & $\begin{array}{c}\text { Weight(Kg) } \\
(\min -m a x)\end{array}$ & $\begin{array}{c}\text { Length(cm) } \\
(\mathrm{min}-\mathrm{max})\end{array}$ \\
\hline Bommidayalu & Channa marulius & Masto symbollon & 733 & $0.10-0.25$ & $10-25$ \\
\hline Ravva & Roho labeo & Lebio rohita & 632 & $0.50-3.20$ & $15-35$ \\
\hline Chanduva & Pomfret-White & Stromateus Sinensis & 630 & $0.30-1.50$ & $13-35$ \\
\hline Nallasandawah & Pomfret-Black & Formio niger & 644 & $0.30-1.50$ & $13-35$ \\
\hline Jallalu & Cat fish & Arius sona & 720 & $0.10-0.20$ & $15-25$ \\
\hline Chandamama & Silver Pomfret & Stromateus sinensis & 621 & $0.05-0.15$ & $10-25$ \\
\hline Bangaru teega & Gold fish & Cyprinus carpio & 587 & $0.50-2.00$ & $10-30$ \\
\hline Korramenu & Soleole & Rastrelliger kanagurta & 698 & $0.50-3.50$ & $15-35$ \\
\hline Royya & Tiger prawn & Panaeus monodon & 570 & $0.10-0.30$ & $05-15$ \\
\hline Royya & Scamil prawn & Macrobrachium & 408 & $0.10-0.20$ & $05-15$ \\
\hline
\end{tabular}

*Data published in Journal of Environmental and Public Health by corresponding author 


\subsection{Sample Preparation for Analysis}

The fish samples were beheaded, gutted, washed and filleted. The primary sample of each species was used to prepare a composite sample. Special care was taken to prevent metal contamination of the samples from laboratory equipment. All laboratory-ware were soaked in $2 \mathrm{M} \mathrm{HNO}_{3}$ for $48 \mathrm{~h}$, and rinsed several times with distilled water and deionized water prior to use. Small size fish were pulverized with skin and the edible portion weight was recorded. Aliquots of edible tissue was taken for analysis of heavy metals and proximate composition and stored in a freezer at $-20^{\circ} \mathrm{C}$ till further analysis.

\subsection{Heavy Metal Analysis}

\subsubsection{Microwave Digestion}

The closed vessel microwave digestion system (CEM-MARS-USA) was used to digest homogenized fish samples (between 0.5 and $1.5 \mathrm{~g}$ ) and placed in a Teflon digestion vessel with $3 \mathrm{ml}$ of ultra-pure $\mathrm{HNO}_{3}$ and $1 \mathrm{ml}$ of Hydrogen Peroxide $\left(\mathrm{H}_{2} \mathrm{O}_{2}\right.$ - Merck). Sealed containers were placed in a microwave oven and heated according to the digestion program (program: Power $1600 \mathrm{~W}$ (100\%), Ramp time 15 minutes, Temperature $200^{\circ} \mathrm{C}$, Hold time 15 minutes and cooling time 15minutes). After digestion, sample solutions were cooled to room temperature and then transferred quantitatively in to acid cleaned $25 \mathrm{ml}$ standard volumetric flasks and made up to $25 \mathrm{ml}$ with double distilled deionized water and prepared under the same conditions as the calibration standards in $6 \%(\mathrm{v} / \mathrm{v}) \mathrm{HNO}_{3} \cdot \mathrm{A}^{\cdot}$ blank digest was carried out in the same way [16].

\subsubsection{Inductively Coupled Plasma Mass Spectroscopy (ICP-MS)}

Nickel, Arsenic Cadmium and Lead in fresh water fish were determined using ICP-MS (PerkinElmer Élan 9000-USA). For better operating conditions the ICP-MS was adjusted to: Nebulizer gas flow $0.91 \mathrm{~L} / \mathrm{min}$, Radio frequency (RF) $1200 \mathrm{~W}$, Lens voltage $1.6 \mathrm{~V}$, Cool gas $13.0 \mathrm{~L} / \mathrm{min}$, and Auxiliary gas $0.70 \mathrm{~L} / \mathrm{min}$ [18]. CRM samples were procured from NIST and EC and used for method standardization, standard graphs were drawn. Recovery study was also done and results were shown in Table-2. The detection ranges of heavy metals in the recovery study were from $96 \%$ to $100 \%$. The description of the data was given as mean $\pm \mathrm{SD}$.

Table 2. Recovery study using Certified Reference Material (CRM)-mg/kg

\begin{tabular}{|c|c|c|c|}
\hline $\begin{array}{c}\text { Name of the } \\
\text { Element }\end{array}$ & $\begin{array}{c}\text { Analyzed } \\
\text { Value }\end{array}$ & Certified Value & $\begin{array}{c}\% \text { of } \\
\text { recovery }\end{array}$ \\
\hline Nickel & $0.163 \pm 0.08$ & $0.17 \pm 0.08$ & 96.0 - NIST \\
\hline Arsenic & $0.048 \pm 0.04$ & $0.05 \pm 0.00$ & $98.7-$-EC \\
\hline Cadmium & $0.110 \pm 0.06$ & $0.11 \pm 0.05$ & $100-$ NIST \\
\hline Lead & $0.224 \pm 0.00$ & $0.23 \pm 0.00$ & $97.3-$ NIST \\
\hline
\end{tabular}

Values are mean \pm SD, $n=6$

NIST: National Institute of Standard Technology

EC: European Commission

\subsubsection{Statistical Analysis}

ANOVA was employed to test the difference between means of various fishes with regard to heavy metals.

\section{Results and Discussion}

The weight and length of the available varieties of fresh water fish and shell fish were shown in Table 1. The fish varieties collected in the present study had shown variation in weights and lengths. Among the varieties studied, $(10-25 \mathrm{~cm}$ and weight is $0.10-0.25 \mathrm{~kg}, 05-15 \mathrm{~cm}$ and weight is $0.10-0.20 \mathrm{~kg}, 15-35 \mathrm{~cm}$ weight is $0.50-3.5 \mathrm{~kg}$ ). In the previous study conducted by Rejomon [19] the length of the fish and shell fish were gradually increased depending on Panaeus monodon and Stromateus sinensis with least length and weight $(05-15 \mathrm{~cm}$ and weight is $0.05-0.15 \mathrm{~kg})$ followed by Masto symbollon, Macrobrachium rosenbergii, and Rastrelliger kanagurta with highest length and weight the weight of the fish. Similar findings were observed in the fish collected for heavy metal analysis in the present study.

\subsection{Proximate Analysis}

Proximate content of moisture, ash, and fat contents was determined using Association of Official Analytical Chemists [20]. Protein content $(N \times 6.25)$ was estimated using AOAC Kjeldahl method [21]. Proximate composition of fresh water fish was as shown in Table 3. Present study reveals that the moisture content of fresh water fish was diverse ranging from $70.19 \%$ in Arius sona and $78.39 \%$ in Cyprinus carpio. Ash content was shown in the range of $0.71 \%$ to $1.12 \%$ in Panaeus monodon and Arius sona. Total minimum and maximum content of protein was observed from $13.25 \%$ to $17.78 \%$ in Arius sona and Pampus argenteus and the level of fat content was ranged from $5.40 \%$ to $15.40 \%$ in Labeo rohita and Arius sona, respectively. These results were similar to those reported by Tuzen et al [22] for sea bass, $76.72 \%$ moisture, $1.23 \%$ ash, $19.43 \%$ protein, and $4.81 \%$ fat. In another study the proximate composition values of fresh water fish range from 65 to $78 \%$ for moisture, 1.19 to $3.92 \%$ for ash, 14 to $18 \%$ for protein, and 1.53 to $5.41 \%$ for fat [23]. Taha et al [24] reported that the ranges of moisture in fish were from 63.52 to $70.71 \%$, of ash from 1.35 to $1.66 \%$, of protein content from 19.81 to $20.35 \%$, and of fat levels from 6.10 to $15.11 \%$, respectively, whereas in another study moisture content was $74.74 \%$, ash contentwas $1.53 \%$, protein content was $18.80 \%$, and fat content was $6.53 \%$ [25]. The proximate parameters also showed $69.91 \%$ for moisture, $1.22 \%$ for ash, $8.25 \%$ for protein, and $10.37 \%$ for fat [26].The proximate composition values in fish were determined in the ranges of $72.22 \%$ of moisture, $1.57 \%$ of ash, $21.08 \%$ of protein, and $6.01 \%$ of fat [27]. It is known that the variations in the chemical composition of fish were closely related to nutrition, living area, fish size, catching season, and seasonal and sexual variations as well as other environmental conditions $[28,29,30]$. The variations in proximate parameters could be due to sexual and environmental conditions. The heavy metal content and proximate composition data in Indian marine fish was also published by the research team from same lab [31]. 
Table 3. Proximate Composition in Fresh water Fish-g\%

\begin{tabular}{|c|c|c|c|c|c|}
\hline Common Name & Scientific name & Moisture & Ash & Protein & Fat \\
\hline Channa marulius & Masto symbollon & $74.08 \pm 1.2$ & $0.997 \pm 0.12$ & $14.02 \pm 0.52$ & $10.05 \pm 1.1$ \\
\hline Roho labeo & Lebio rohita & $76.29 \pm 0.9$ & $1.076 \pm 0.11$ & $16.39 \pm 0.45$ & $5.4 \pm 0.85$ \\
\hline Pomfret-White & Pompus argenteus & $75.15 \pm 1.5$ & $1.067 \pm 0.23$ & $14.72 \pm 0.78$ & $9.15 \pm 1.34$ \\
\hline Pomfret-Black & Pompus argenteus & $75.26 \pm 0.82$ & $0.956 \pm 0.12$ & $17.78 \pm 0.85$ & $6.2 \pm 0.46$ \\
\hline Cat fish & Arius sona & $70.19 \pm 1.21$ & $1.125 \pm 0.31$ & $13.25 \pm 0.23$ & $15.4 \pm 1.85$ \\
\hline Silver Pomfret & Stromateus sinensis & $75.01 \pm 1.43$ & $0.778 \pm 0.09$ & $11.71 \pm 0.13$ & $12.55 \pm 1.23$ \\
\hline Gold fish & Cyprinus carpio & $78.39 \pm 1.89$ & $0.776 \pm 0.14$ & $15.56 \pm 0.53$ & $5.48 \pm 0.46$ \\
\hline Soleole & Rastrelliger kanagurta & $73.42 \pm 1.46$ & $1.023 \pm 0.21$ & $15.12 \pm 0.52$ & $10.45 \pm 1.78$ \\
\hline Tigar prawn & Panaeus monodon & $76.11 \pm 0.82$ & $0.717 \pm 0.37$ & $14.24 \pm 0.37$ & $9.00 \pm 0.99$ \\
\hline Scamil prawn & $\begin{array}{c}\text { Macrobrachium } \\
\text { rosenbergii }\end{array}$ & $76.99 \pm 0.79$ & $0.816 \pm 0.35$ & $13.4 \pm 0.42$ & $8.8 \pm 0.86$ \\
\hline
\end{tabular}

Values are Mean $\pm \mathrm{SD}, \mathrm{n}=6$

\subsection{Heavy Metal Analysis}

Heavy metals such as Cadmium (Cd), Lead $(\mathrm{Pb})$, Nickel (Ni) and metalloids such as Arsenic (As) are very stable and cannot be destroyed or degraded in their inorganic elemental form. Fresh water fish and shell fish were susceptible to accumulate these heavy metals from their aquatic environment. Shellfish in particular can be high in Cd levels. Arsenic is found in different chemical forms, where inorganic arsenic is regarded as potentially more toxic than organic species. Fish and shellfish mainly tend to accumulate organic arsenic [32. The range of values for weight and the length of different varieties of fresh water fish and shell fish along with binomial and vernacular nomenclature are presented in Table 1. There was a high degree of variability in biometric values of weight and length among the available fish varieties with least length and weight of 05 to $15 \mathrm{~cm}$ and 0.05 to $0.15 \mathrm{Kg}$ respectively recorded for Panaeus monodon and Stromateus sinensis and highest length and weight of 15 to $35 \mathrm{~cm}$ and 0.5 to $3.5 \mathrm{~kg}$ respectively been recorded for Lebio rohita and Rastrelliger kanagurta. [33] Oribhabor et al [34] Gokhan et al have reported that the length of the fresh water fish, marine fish and shell fish alter depending upon the weight of the fish. Among the 10 different fresh water fishes studied, the Nickel content ranged from 52.31 to $680 \mu \mathrm{g} / \mathrm{kg}$, Arsenic content ranged from 37.85 to 689.5 $\mu \mathrm{g} / \mathrm{kg}$, Cadmium content ranged from 3.12 to $61.87 \mu \mathrm{g} / \mathrm{kg}$ and Lead content ranged from 26.56 to $108.2 \mu \mathrm{g} / \mathrm{kg}$ respectively. The average contents of $\mathrm{Ni}, \mathrm{As}, \mathrm{Cd}$ and $\mathrm{Pb}$ in all the 10 different fishes studied were 157.4, 348.5, 13.6 and $61.5 \mu \mathrm{g} / \mathrm{kg}$ respectively. The specific contents of Nickel, Arsenic, Cadmium and Lead quantified using MD-ICP-MS in different species of fresh water fish and shell fish were provided in Table 4.

\subsection{Nickel content in Fresh Water Fish and Shell Fish}

Higher concentrations of Ni was observed in fishes such as Stromateus sinensis, Pompus argenteus and Masto symbollon with average $\mathrm{Ni}$ contents of $680.1,148.3$ and $116.5 \mu \mathrm{g} / \mathrm{kg}$ respectively. Among 10 different fishes evaluated median range Ni contents was noticed in Arius sona and Lebio rohita with mean Ni contents of 66.17 and $63.51 \mu \mathrm{g} / \mathrm{kg}$ respectively. Lower concentrations of $\mathrm{Ni}$ were found in Rastrelliger kanagurta with $52.31 \mu \mathrm{g} / \mathrm{kg}$ of $\mathrm{Ni}$ accumulation. In the present study the levels of $\mathrm{Ni}$ in fresh water fish and shell fish varieties were found to vary from a minimum of $52.31 \mu \mathrm{g} / \mathrm{kg}$ in in Rastrelliger kanagurta andto a maximum of $680 \mu \mathrm{g} / \mathrm{kg}$ Stromateus sinensis. Generally Ni concentration may be low in aquatic environment and is found in several oxidation states ranging from -1 to +4 . However the +2 oxidation state $\left(\mathrm{Ni}^{+2}\right)$ is the most common in biological systems ${ }^{24}$ which was the state determined in the present study as well [3]. When compared to the values of $\mathrm{Ni}$ that ranged from 0.2 to $3.97 \mathrm{mg} / \mathrm{kg}$ in Rastrelliger brachysoma from Aegean and Mediterranean Sea [35]. Ni concentrations in fresh water fish in the present study were lower. In another similar study the concentration of $\mathrm{Ni}$ ranged from 0.03 to $0.069 \mathrm{mg} / \mathrm{kg}$ in muscle tissues of fish from Indian markets [36] (Sivaperumal et al and [37] Turkmen et al as well also reported that the Ni concentrations values of 0.66 to $1.59 \mathrm{mg} / \mathrm{kg}$ in muscle tissues of fish from Iskenderun bay, Mediterranean Sea; 0.009 to $0.011 \mathrm{mg} / \mathrm{kg}$ in muscle tissue and 0.07 to $0.10 \mathrm{mg} / \mathrm{kg}$ in livers tissues of fish from Mediterranean region. Similarly Nawal Al-Bader [38] (FSANZ) presented the concentrations $\mathrm{Ni}$ that varied from 1.92 to $5.68 \mathrm{mg} / \mathrm{kg}$ in M. merlangus and Mugil cephalous. In the present study, the content of $\mathrm{Ni}$ varied significantly among different fish varieties (Table 4).

\subsection{Arsenic Content in Fresh Water Fish and Shell Fish}

The level of Arsenic toxicity largely depends on its chemical form, which means that exposure to inorganic Arsenic could be highly harmful. Determination of arsenic in biological tissues is cumbersome due to the presence of interferences, difficulties in mineralization of some organic Arsenic species such as Arsenobetaine which is a predominant arsenic species in fish tissues. The interferences in the determination of arsenic could be minimized using sophisticated techniques such as ICP-MS as compared to other techniques like ICP-AES and AAS. Higher concentrations of arsenic were found in Pompus argenteus 
and Arius sona with mean contents of 689.5, 686.4 and 586.1 $\mu \mathrm{g} / \mathrm{kg}$ respectively. Median concentrations of As was noticed in Cyprinus carpio and Macrobrachium rosenbergii with mean contents of 23.1 , and $204.7 \mu \mathrm{g} / \mathrm{kg}$ respectively. Lower As contents of 37.85 and $42.16 \mu \mathrm{g} / \mathrm{kg}$ were obtained in Rastrelliger kanagurta and Masto symbollon respectively. There was a significant difference between the different fish species and the levels were found to be higher than previous reports. Similar values of Arsenic were reported in black and whitespecies of Lates calcarifer. [37] Turkmen et al have shown that the As levels in fish were in the range of 0.25 to $0.42 \mathrm{mg} / \mathrm{kg}$. Reports of total Arsenic concentrations in fish and crustacean in food standards were not found, the maximum limit of As concentration being of $2 \mathrm{mg}$ (inorganic As) $/ \mathrm{kg}$ [38]. The study reveals that higher level of arsenic content is could be observed in Pompus argenteus. Such prominent content of Arsenic in various fish species may be attributed to the extensive upwelling occurring in the area, which brings Arsenic rich sub-surface waters to the surface.

\subsection{Cadmium Content in Fresh Water Fish and Shell Fish}

Among all the 10 fishes studied, Cadmium contents were found to higher in Pompus argenteus, and Macrobrachium rosenbergii with average contents of 61.87 and $23.77 \mu \mathrm{g} / \mathrm{kg}$ respectively. Lower concentrations of $\mathrm{Cd}$ were observed in Masto symbollon, Panaeus monodon and Rastrelliger kanagurta with mean $\mathrm{Cd}$ content of 3.12, 3.53 and 3.95 $\mu \mathrm{g} / \mathrm{kg}$ and these fish were contained similar levels of $\mathrm{Cd}$ but Cd content was significantly different in Arius sona with $11.63 \mu \mathrm{g} / \mathrm{kg}$. Mustafa et al (2002) have reported that $\mathrm{Cd}$ values of marine fish were found to range from 0.02 to 0.37 $\mathrm{mg} / \mathrm{kg}$ in Trigla gurnardusand Silonella aurata. Another study revealed that $\mathrm{Cd}$ concentrations in fish from lakes in Tokat, Turkey were 0.1 to $1.2 \mathrm{mg} / \mathrm{kg}$ [21]. Cd levels ranged from 0.02 to $1.32 \mathrm{mg} / \mathrm{kg}$ in muscle tissues of fish obtained from internal markets of India [36]. Cd levels in Mugil cephalusand Mugil barbatus ranged between 0.450 to 0.900 $\mathrm{mg} / \mathrm{kg}$ [39]. In another similar study the Cd levels were found to be in the range of 90 to $480 \mu \mathrm{g} / \mathrm{kg}$ of dry weight in fish samples of the middle Black Sea, Turkey [21]. In another study the $\mathrm{Cd}$ concentrations were 0.10 to 0.840 $\mathrm{mg} / \mathrm{kg}$ of fish [22]. Cadmium concentrations were similar in all the fresh water fishes except Pompus argenteus,
Stromateus sinensis and Arius sona with minimum $\mathrm{Cd}$ concentration observed in Masto symbollon. In natural water Cadmium is rarely found [23]. Cadmium is considered to be toxic if its concentration exceeds $0.01 \mathrm{mg} / \mathrm{L}$ both in drinking and irrigation water [24]. Cadmium with some other heavy metals lead and mercury do not have any known biological or metabolic function in human system and are potentially toxic even at trace concentrations [25]. Acute cadmium toxicity causes high blood pressure, kidney damage, destruction of testicular tissue and red blood cells [26].

\subsection{Lead Content in Fresh Water Fish and Shell Fish}

Lead is considered as a non-essential and toxic metal which also implies that it has no known function in biochemical processes. Lead induces reduced cognitive development and intellectual performance in children and increased blood pressure and cardiovascular disease in adults [27]. Lead contents were found to be highly variable amongst all the different 10 fish studied. Rastrelliger kanagurta, Arius sona and Pompus argenteus contained comparatively higher $\mathrm{Pb}$ concentrations with values of 108.2 , 87.66 and $77.35 \mu \mathrm{g} / \mathrm{kg}$ respectively. Lower concentrations of $\mathrm{Pb}$ of 26.56 and $35.66 \mu \mathrm{g} / \mathrm{kg}$ were found in Panaeus monodon and Macrobrachium rosenbergii respectively. The levels of $\mathrm{Pb}$ in the present study were estimated to be a minimum of $26.56 \mu \mathrm{g} / \mathrm{kg}$ in Panaeus monodon and a maximum of 108.2 in $\mu \mathrm{g} / \mathrm{kg}$ Rastrelliger kanagurta. [20] Mustafa et al have found that the levels of $\mathrm{Pb}$ in fish ranged from 0.33 to $0.86 \mathrm{mg} / \mathrm{kg}$ in Trigla gurnardusand Dracunculus vulgaris respectively. Another marine study reveals that the $\mathrm{Pb}$ contents were in the range between 0.33 to $0.93 \mathrm{mg} / \mathrm{kg}$ in muscles tissues of fish in Black and Aegean seas [28]. Concentrations of Lead in Engraulis encrasicholus and Merlangius merlangusfishes in Black and Aegean Seas were found to be in the range of 0.33 to $0.93 \mathrm{mg} / \mathrm{kg}$ [29]. Similarly [30] Dural et al have also reported that the $\mathrm{Pb}$ contents were in the range of 0.40 to $2.44 \mathrm{mg} / \mathrm{kg}$ in muscle and 1.41 to $3.95 \mathrm{mg} / \mathrm{kg}$ in liver tissues of fish of Tulza Lagoon. Previous studies have demonstrated that the $\mathrm{Pb}$ levels were varied with different parts of fish such as flesh, guts, and gills etc. In general $\mathrm{Pb}$ levels were found in the order of gill $>$ liver $>$ flesh $[31,40]$.

Table 4. Heavy metal content in fresh water fish- $\mu \mathrm{g} / \mathrm{kg}$

\begin{tabular}{|c|c|c|c|c|c|}
\hline \multirow{2}{*}{ Common Name } & \multirow{2}{*}{ Scientific Name } & \multicolumn{4}{|c|}{ Name of the elements } \\
\cline { 3 - 6 } & & Nickel & Arsenic & Cadmium & Lead \\
\hline Channa marulius & Masto symbollon & $116.5 \pm 0.66$ & $42.16 \pm 0.44$ & $3.12 \pm 0.37$ & $40.56 \pm 0.7$ \\
\hline Roho labeo & Lebio rohita & $63.51 \pm 0.72$ & $529.1 \pm 0.55$ & $4.36 \pm 0.25$ & $47.22 \pm 0.6$ \\
\hline Pomfret-White & Pompus argenteus & $148.3 \pm 0.63$ & $586.1 \pm 0.28$ & $5.65 \pm 0.35$ & $77.35 \pm 0.7$ \\
\hline Pomfret-Black & Pompus argenteus & $168.3 \pm 0.72$ & $689.5 \pm 0.42$ & $61.87 \pm 0.9$ & $35.73 \pm 0.6$ \\
\hline Cat fish & Arius sona & $66.17 \pm 0.75$ & $686.4 \pm 0.96$ & $11.63 \pm 0.8$ & $87.66 \pm 0.8$ \\
\hline Silver Pomfret & Stromateus sinensis & $680.1 \pm 0.77$ & $66.95 \pm 0.77$ & $12.95 \pm 0.5$ & $87.1 \pm 0.71$ \\
\hline Gold fish & Cyprinus carpio & $95.25 \pm 0.84$ & $237.1 \pm 0.42$ & $5.25 \pm 0.49$ & $68.8 \pm 0.84$ \\
\hline Soleole & Rastrelliger kanagurta & $52.31 \pm 0.65$ & $37.85 \pm 0.49$ & $3.95 \pm 0.21$ & $108.2 \pm 0.9$ \\
\hline Tigar prawn & Panaeus monodon & $103.8 \pm 0.35$ & $405.8 \pm 0.45$ & $3.53 \pm 0.51$ & $26.56 \pm 0.8$ \\
\hline Scamil prawn & Macrobrachium rosenbergii & $80.17 \pm 0.80$ & $204.7 \pm 0.65$ & $23.77 \pm 0.6$ & $35.66 \pm 0.5$ \\
\hline
\end{tabular}

Values are Mean $\pm \mathrm{SD}, \mathrm{n}=6$ 
The concentrations of heavy metal in fish may vary in different species and different aquatic environments [41]. Fish species have the potential to accumulate heavy metals above the biotic environment which is known as bioaccumulation. The observed variation in the pattern of heavy metal bioaccumulations in different species might be due to the difference in feeding habits, habitats and physiology, the ability of organisms to digest the metals and the concentration of such metals in the aquatic medium [42]. Fishes mainly take up the metals from the water, food sources and sediment [41]. The efficiency of metal uptake from contaminated water and food depends upon the ecological needs, metabolism, and the contamination gradient of water, food and sediment, environmental factors such as $\mathrm{pH}$, salinity and temperature [43, 44].

Various anthropogenic activities such as domestic sewage, combustion, emission, mining, metallurgical activities and industrial effluents cause the heavy metal inputs into the environments. Assessment of metal contamination of fish is important to determine the safety aspects of consumption and such pertinent data is scanty. In food sources, the allowed quantity of heavy metals is defined by norms, which are based both on the WHO recommendations and local requirements. World Health Organization (WHO) recommends that daily intake of $\mathrm{Ni}$ and $\mathrm{As}$ in the inorganic form of 100 to $300 \mu \mathrm{g} / \mathrm{kg}$ and up to $15 \mu \mathrm{g} / \mathrm{kg}$ of body weight as safer limits for humans. The maximum permissible levels of $\mathrm{Cd}$ and $\mathrm{Pb}$ were 0.05 to $5.5 \mathrm{mg} / \mathrm{kg}$ and 0.5 to $6.0 \mathrm{mg} / \mathrm{kg}$ in fish respectively. As per the National Nutrition Monitoring Bureau (NNMB), National Institute of Nutrition (NIN, ICMR) an average household consumption of fish in Andhra Pradesh is $6 \mathrm{~g} / \mathrm{CU} / \mathrm{day}$ [45]. The consumption of fish is very low compared to the recommended levels of WHO/FAO [32]. In this context the heavy metal levels in fresh water fish observed in the present study was below the recommended level of WHO and previous literature. The present study findings indicating that the consumption of fish available in twin cities of Hyderabad and Secunderabad may not have any adverse heavy metal toxic effects on human health.

\section{Conclusions}

Present study was in conformation with FAO/WHO and literature values for heavy metal contents in fresh water fish. Weekly intakes of heavy metals through fish consumption were below the provisional tolerable levels as recommended by $\mathrm{WHO} / \mathrm{FAO}$. It is known that a variation in the mineral composition of fresh water foods is closely related to seasonal and biological differences (Species, size, dark/white muscle, age, sex and sexual maturity), area of catch, processing method, food source and environmental conditions. For monitoring and evaluation of the ecological conditions of fish, such fish metal accumulation pattern can be helpful. In order to develop aquaculture industry in water resources it is necessary to maintain water quality standards, and to monitor contamination levels of water sources and that of fish regularly. The chemical nature of the metals, ionic strength and $\mathrm{pH}$ also play critical role variable in the accumulation patterns. This study may provide information on the important heavy metal concentrations of fresh water fish and shell fish consumed in twin cities of Hyderabad and Secunderabad, and therefore provides an essential baseline data with which future levels may be compared and evaluated.

\section{REFERENCES}

[1] Schmidt, E. B, Rasmussen, L. H, Rasmussen, J. G. Jensen, A. M. Madsen, M. B. and Christensen, J. H. " Fish, marine n-3 polyunsaturated fatty acids and coronary heart disease," A mini review with focus on clinical trial data. Prostaglandin, Leukotrienes and Essential Fatty Acids, 75(3): 191-195 (2006)

[2] Anderson, P. D, Wiener, J. B, Graham, J. D. and Weiner, J. B. "Risk versus Risk. Tradeoffs in Protecting Health and the Environment," Hazard University Press, Cambridge, MA, USA. (1995)

[3] Denkhaus, E. and Salnikow, K. "Nickel essentiality, toxicity and carcinogenicity," Critical Review. Oncol./Hematol, 42: 35-56 (2002)

[4] Patterson, J. "Introduction- comparative dietary risk: Balance the risks and benefits of fish consumption," Comments Toxicology, 8: 337-344 (2002)

[5] Jhingaram, V. G. "Fish and Fisheries of India," Hindustan Publishing Corporation, India. (1985)

[6] Bal, D. V. and Virabhadra Rao, K. "Marine Fisheries," Tata McGraw-Hill, New Delhi. (1984)

[7] Fisheries Research Institute. Field guide to selected commercial marine fishes of Malaysian waters. Malaysia. Fisheries Research Institute (2004)

[8] Mc Lintock, A. H. (Ed) Te Ara-The Encyclopedia of New Zealand. Fish Marine. (2007)

[9] Munoz-Olivas, R. and Camara, C. "Speciation related to human health. In Ebdon, L. Pitts, L. Cornelis, R. Crews, H, Donard, O. F. X. and P. Quevauviller (EDs) Trace element speciation for environment food and health," The Royal Society of Chemistry, 331-353 (2001)

[10] Jarup, L. Berglund, M. Elinder, C. G. Nordberg, G. and Vahter, M. Scand, J. "Work. Environ. Health," 24 Suppl. 1: 1-51 (1998)

[11] $\mathrm{Hu}, \mathrm{H}$. "Exposure to Metals. Primary Care," 27 (4): 983-996 (2000)

[12] Robards, K. and Worsfold, P. Analyst, 116: 549-568 (1991)

[13] Graeme, K. A. and Jr. Pollack, C. V. Journal of Emerg. Med, 16: 171-177 (1998)

[14] International Agency for Rearch on Cancer (IARC). "Monographs on the evolution of carcinogenic risks to humans- Arsenic and Arsenic compounds," Vol. 23 IARC Press, Lyon, France, 39-141 (1980) 
[15] Sampath, V. "Living Resources of India s Exclusive Economic Zone,” In Qasim, S. Z, Roonval, G. S (Eds) (1998)

[16] Ozgur Dogan Uluozlu. Tuzen, M. Mendil, D. and Soylak, M. "Trace metal content in nine pecies of fish from the Black and Aegean Seas Turkey," Food Chemistry, 104: 835-840 (2007)

[17] Greenfield, H. and Southgate, D. A. T. "Food Composition Data, Production, Management and use, 2nd edition. Rome," Food and Agriculture Organization of United Nations, (2003)

[18] Laurent Noel. Vincent Dufailly. Nadege Lemahieu. Christelle Vastel. and Thierry Guerin. "Simultaneous analysis of Cadmium, Lead, Mercury, and Arsenic content in foodstuffs of animal origin by Inductively Coupled Plasma/Mass Spectrometry after closed vessel microwave digestion, Method Validation," Journal of AOAC International, Vol. 88 (6) (2005)

[19] Rejomon, G. "Biogeochemistry of trace elements in the Indian Exclusive Economic Zone (EEZ) of the Arabian Sea and Bay of Bengal. Doctoral Thesis, Cochin University of Science and Technology, India," (2005)

[20] Mustafa, T. Aysun, T. Yalcm, T. Alpaslan, A. and Kutalmis, G. "Determination of metal content in sea foods from Marmara, Aegean and Mediterranean seas, Twelve fish species," Food Chemistry, 108: 794-800 (2002)

[21] Mendil, D. Uluozlu, O. D. Hasdemir, E. Tuzen, M. Sari, H. and Suicmez M. "Determination of trace metal levels in seven fish species in lakes in Tokat, Turkey," Food Chemistry, 90: 175-179 (2002)

[22] Tuzen, M. "Determination of heavy metals in fish samples of the middle black sea (Turkey) by graphite furnace atomic absorption spectrometry," Food Chemistry, 80: 119-123 (2002)

[23] Hem, J. D. Lind, C. J. and Roberson, C. E. "Coprecipitation and redox reactions of manganese oxides with copper and nickel. Geochimica et Cosmochimica Acta," 53(11): 2811-2822 (1989)

[24] Taha, A. A. El-Mahmoudi, A. S. and El-Haddad, I. M. "Pollution sources and related environmental impacts in the new communities southeast Nile Delta, Egypt. Emirates," Journal of Eng. Res, 9(1): 35-49 (2004)

[25] Robert, G. “Toxic effects of metals. In Casarett and Doull's toxicology. Pergamon Press,” 662-672 (1991)

[26] Gupta, B. N. and Mathur, A. K. "Toxicity of heavy metals," Ind. J. Med. Sci, 37: 236-240 (1983)

[27] Commission of the European Communities (2001). Commission Regulation (EC) No. 221/2002 of 6 February 2002 amending regulation (EC) No. 466/2002 setting maximum levels for certain contaminants in foodstuffs. Official Journal of the European Communities, Brussels, 6 February (2002)

[28] Uluozlu, O. U. Tuzen, M. Mendil, D. and Soylak, M. "Trace metal content in nine species of fish from the Black and Aegean Seas, Turkey," Food Chemistry, 104: 835-840 (2007)

[29] Uluturhan, E. and Kucuksezgin, F. "Heavy metal contents in Red Pandora (Pagellus erythrinus) tissues from the Eastern Agean Sea, Turkey," Water Research, 41: 1185-1192 (2002)

[30] Dural, M. Goksu, M. Z. L. and Ozak, A. A. "Investigation of heavy metal levels in economically important fish species captured from the Tulza lagoon," Food Chemistry,102: 415-421 (2002)

[31] Mansour, S. A. and Sidky, M. M. "Ecotoxicological studies. 3, Heavy metals containing water and fish from Fayoum Governate, Egypt," Food Chemistry, 78:15-22 (2002)

[32] WHO. "Evolution of certain food additives, 61st report of the joint FAO/WHO Expert Committee on Food Additives, World Health Organization Technical Report Series 922, World Health Organization, Geneva," (2011)

[33] Oribhabor, B. J. Ogbeibu, A. E. and Udo, M. T. "The Length-Weight Relationships of Brackish Water/Marine Fish Species Assemblage in a Niger Delta Mangrove Creek, Nigeria," Current Research Journal of Biological Sciences, 3(6): 616-621 (2011)

[34] Gokhan Gokce., Mustafa Cekic. and Halit Filiz. "Length-weight relationships of marine fishes off Yumurtalık coast (İskenderun Bay), Turkey," Turkey Journal of Zoology, 34 101-104 (2010)

[35] AOAC Official methods of analysis, 18th edition [revised]. Association of Official Analytical Chemists, Washington DC (2006)

[36] Sivaperumal, P. T. V. Sankar, T. V. and Nair, P. G. V. "Heavy metal concentrations in fish, shellfish products from internal markets of India Vis-a- Vis international standards," Food Chemistry, 102: 612-620 (2002)

[37] Turkmen, A. M. Turkmen, M. Type, Y. Mazlum, I. and Oymael, S. "Heavy metals levels in blue crab (Callinects sapidus) and Mullet (Mugil cepephalus) in Iskenderum Bay (North eastern Mediterranean, Turkey)," Bulletin of Environmental Contamination and Toxicology, 77: 186-193 (2002)

[38] FSANZ. "Food standards code, Food safety standards 1. 4. 1, Food standards Australia, Newzealand," (2004)

[39] Turkmen, M. and Ciminli, C. "Determination of metals in fish and mussel species by inductively coupled plasma-atomic emission spectrometry," Food Chemistry, 103: 670-675 (2002)

[40] Kalay, M. Ay, O. and Canli, M. "Heavy metal concentrations in fish tissues from the North East Mediterranean sea," Bull. Envoron. Cantam. Toxicology, 63: 673-681 (1999)

[41] Canli, M. and Atli, G. "The relationships between heavy metal $(\mathrm{Cd}, \mathrm{Cr}, \mathrm{Cu}, \mathrm{Fe}, \mathrm{Pb}, \mathrm{Zn})$ levels and the size of six Mediterranean fish species," Environmental pollution, 121(1): 129-136 (2003)

[42] Arellano, J. M. Storch, V. and Sarasquete, C. "Histological Changes and Copper Accumulation in Liver and Gills of the Senegales Sole, Solea senegalensis," Ecotoxicology and Environmental Safety, 44(1): 62-72 (1999)

[43] Heath, A. G. "Water pollution and Fish physiology," CRC press, Florida, USA, 245 (1987)

[44] Pagenkopf, G. K. "Gill surface interaction model for trace metal toxicity to fish. Role of complexation, $\mathrm{PH}$, water hardness," Environ. Sci. Technol, 17/ 6: 342-347 (1983)

[45] National Nutrition Monitoring Bureau Report, National Institute of Nutrition, (NIN, ICMR) (2006) 